(Research Laboratory, British Museum) stressed the wider concept of conservation which involved successively preventive treatment, diagnosis of the causes of decay, research in the evaluation of new synthetic materials and scientific examination of the object before attempting treatment. Mr. H. W. M. Hodges (Institute of Archæology) said that at present there were only two academic training institutions in the world for conservators-in London and in New York. He detailed the training given in London and emphasized that conservation must be based on scientific knowledge. Mr. A. E. Rixon (British Museum
(Natural History)) gave details of useful techniques for dealing with the preservation of fossils.

At the annual general meeting, Dr. Mary Woodall (Birmingham) was elected president for the ensuing year, and an invitation to hold the conference in Brussels in 1962 was accepted with gratitude.

Social events during the week included a civic reception and an annual dinner. At the end of the week organized tours to many of the museums and beauty spots in Devon and North Cornwall brought a memorable conference to a close.

F. S. Wartis

\title{
DIGITAL COMPUTERS, THEIR USE AND CONTROL
}

\begin{abstract}
A SYMPOSIUM on "Digital Computers, Their Use and Control" was organized by the Mathematics Department of Queen's College, University of St. Andrews, in collaboration with Standard Telephones and Cables, Ltd., during May 29-June 2. Standard. Telephones and Cables, Ltd., provided the use of a Stantec Zebra computer for the whole course.

The first day was devoted to talks of a general nature to give a general appreciation of the use of computers. After an address of welcome by the Master of Queen's College, Prof. A. A. Matheson, Dr. R. J. Ord-Smith of Standard Telephones and Cables, Ltd., spoke on computer applications and this was followed by an address by Mr. W. A. Donaldson of Rolls Royce, Glasgow, entitled "Computers in Industry". The morning session was completed by a description of a transportation problem and its solution by Mr. W. A. E. Pillow of Standard Telephones and Cables, Ltd.

In the afternoon the symposium split into two sections. Those who wished to attend the whole course were given a demonstration of Zebra programmes and the remainder were given a brief introduction to programming.
\end{abstract}

The first day was attended by about eighty people of whom about thirty-five were from local industry and commerce and the remainder from the University. On subsequent days, about fifty people attended of whom ten were from outside the University.

The lectures on the remaining days were given largely by Dr. R. J. Ord-Smith and Mr. A. Y. Cooper of Standard Telephones and Cables, Ltd. They covered a comprehensive use of the Zebra simple code and an introduction to normal code. A lecture on "The Computer in the University" was given by Dr. A. J. Cole of Queen's College. By the end of the week, all delegates had written and run several programmes.

The members of Queen's College staff are grateful to Standard Telephones and Cables, Ltd., for providing such excellent facilities and in particular for the continued loan of a Zebra computer, which, in the week subsequent to the course had been in continual use for $8 \mathrm{hr}$. a day.

\section{A. J. COLE \\ J. IBaLL}

\section{A NEW APPROACH TO BIOLOGY TEACHING}

\begin{abstract}
CONFERENCE, proposed and financed by the Gulbenkian Foundation, was held in the University of Birmingham during April 10-12, to discuss the biology syllabus for sixth forms, proposed by the Biology Panel of the Gulbenkian Enquiry 1959*. The conference was attended by seventy-five schoolteachers and several lecturers from teacher-training colleges. The majority of the members came from the West Midlands. Several topics were selected from the syllabus and a lecture was given on each.

During his introductory lecture Prof. O. E. Lowenstein pointed out that the University of Birmingham will be offering a new type of biological training in the near future. This will consist of an honours B.Sc. degree in biological sciences. Undergraduates will take a variety of biological courses which will cut across the traditional subject-boundaries and be in closer accord with the trends in modern biology in pure and applied research, in industry, in agriculture, etc. Various subject-combinations will be possible.

* Copies can be obtained from the Registrar, The University, Birmingham 15 .
\end{abstract}

It is anticipated that fewer students will complete courses of the traditional type leading to a degree in zoology or botany, although it will still be possible to specialize in selected branches of biology, for example, systematic botany, entomology, etc. It is difficult to predict whether other universities will adopt similar schemes; but the wind of change is blowing in this direction and during recent years in many university departments, even within the traditional courses of zoology and botany, the subjectmatter has changed dramatically. Already in Birmingham the preliminary (= intermediate) course in biology has ceased to be virtually separate courses in botany and zoology and is now a closely integrated course following the lines recommended in the Gulbenkian Report.

It is against such a background of a rapidly evolving subject that this new approach to biology in sixth forms is presented.

During discussion there emerged considerable agreement on the need for a new approach, both to teaching and to examining, of the type put forward in the Gulbenkian syllabus, although it was recog- 